\title{
33. THE POST JURASSIC SEDIMENTARY SEQUENCE ON THE PACIFIC PLATE; A KINEMATIC INTERPRETATION OF DIACHRONOUS DEPOSITS ${ }^{1}$
}

\author{
B. C. Heezen ${ }^{2}$, I. D. MacGregor ${ }^{3}$, H.P. Foreman ${ }^{4}$, G. Forristall ${ }^{5}$, H. Hekel ${ }^{6}$, R. Hesse ${ }^{7}$, \\ R. H. Hoskins ${ }^{8}$, E. J. W. Jones ${ }^{9}$, A. Kaneps ${ }^{10}$, V. A. Krasheninnikov ${ }^{11}$, H. Okada ${ }^{12}$, and M. H. Ruef ${ }^{13}$
}

\begin{abstract}
The sea floor of the western Pacific is covered by five stratigraphic units: (1) an eastward thinning wedge of late Tertiary silty clay, primarily of volcanic origin, (2) a Cretaceous to Tertiary zeolitic red clay, (3) a Late Cretaceous to Tertiary chalk/chert sequence, (4) a Cretaceous clay, and (5) a basal chalk/chert sequence. The basal chalk was deposited on the young crust at the crest of the mid-oceanic ridge, while the upper chalk was deposited beneath the equator, and the abyssal clays were deposited in abyssal depths in mid latitudes. A kinematic model has been constructed that outlines the deposition of these units on growing crust, which not only was displaced westward away from the accretion center of the mid-oceanic ridge, but northward under the equator. The average northward component of motion for the Pacific plate has been $2 \mathrm{~cm}$ per year from 0 to $30 \mathrm{~m} . \mathrm{y}$. and $4.4 \mathrm{~cm}$ per year from 30 to $100 \mathrm{~m} . \mathrm{y}$.

The deep-sea deposits of the Pacific are basically and systematically time transgressive. Claims of general synchroneity for either lithostratigraphy or acoustostratigraphy are rejected as inconsistent with both the drilling data and the kinematic model of Pacific pelagic stratigraphy. A few more well sampled holes in the ancient Pacific plate combined with an appropriately refined kinematic model should yield a rather detailed history of the Pacific plate since the Jurassic.
\end{abstract}

\section{INTRODUCTION}

Beneath the thin (20-100 m) unlithified layer of red clay which floors the western Pacific abyss lies a thicker ( $300 \mathrm{~m})$ sequence of chalk, chert, and clay. The boundary at the base of the red clay blanket is broadly time transgressive, varying in age from Early Cretaceous in the west to late Cenozoic in the east. Since there has been a general tendency to attribute a precise synchroneity to pelagic stratigraphy, this evidence of widespread and apparently systematic diachronism introduces a new way of looking at oceanic stratigraphy. In fact, evidence of the time

\footnotetext{
${ }^{1}$ Lamont-Doherty Geological Observatory, Contribution No. 2012 .

${ }^{2}$ Lamont-Doherty Geological Observatory, Palisades, New York.

${ }^{3}$ University of California, Davis, California.

${ }^{4}$ Oberlin College, Oberlin, Ohio.

${ }_{6}^{5}$ Shell Development Co., Houston, Texas.

${ }_{7}^{6}$ Geological Survey of Queensland, Brisbane, Australia.

${ }_{8}^{7}$ McGill, University, Montreal, Canada.

${ }_{9}^{8} \mathrm{New}$ Zealand Geological Survey, Lower Hutt, New Zealand.

9 University College, London, United Kingdom.

${ }^{10}$ Scripps Institution of Oceanography, La Jolla, California.

${ }^{11}$ Geological Institute of the Academy of Sciences of the U.S.S.R., Moscow, U.S.S.R.

${ }_{13}^{12}$ Kagoshima University, Kagoshima, Japan.

${ }^{13}$ State of Washington Department of Ecology, Olympia, Washington.
}

transgressive nature of pelagic stratigraphy has been accumulating since the beginning of the Deep Sea Drilling Project (Maxwell, Von Herzen, et al., 1970; McManus, Burns, et al., 1970; and Fischer, Heezen et al., 1971). In our work during Leg 20, we extended observations of this phenomenon to the oldest known areas of the Pacific crust (Heezen, McGregor, et al., 1972). In interpreting the sediments drilled, we have employed a kinematic model of pelagic deposition which offers a general explanation of the time transgressive sedimentary sequences of the Pacific basin. In a general fashion the model may in fact be applied to the stratigraphic succession on any oceanic plate.

\section{SEDIMENTARY SEQUENCE}

\section{Lithology}

The following lithologic units were encountered (Figure 1). In the region seaward of the Japan Trench (Sites 194 through 198), these units include a stratigraphic succession of Neogene gray silty clays, an Early Cretaceous to Neogene unit of darker brown zeolitic clay, and a Cretaceous unit of chalks, cherts, marls, and siliceous limestones. In the Caroline Abyssal Plain (Hole 199), there occurs a comparable chalk-chert sequence of Cretaceous age which is overlain by alternating layers of zeolitic clay and nannofossil and radiolarian ooze. Ita Mai Tai Seamount at the northeastern margin of Caroline Abyssal Plain is covered with foraminiferal ooze. 

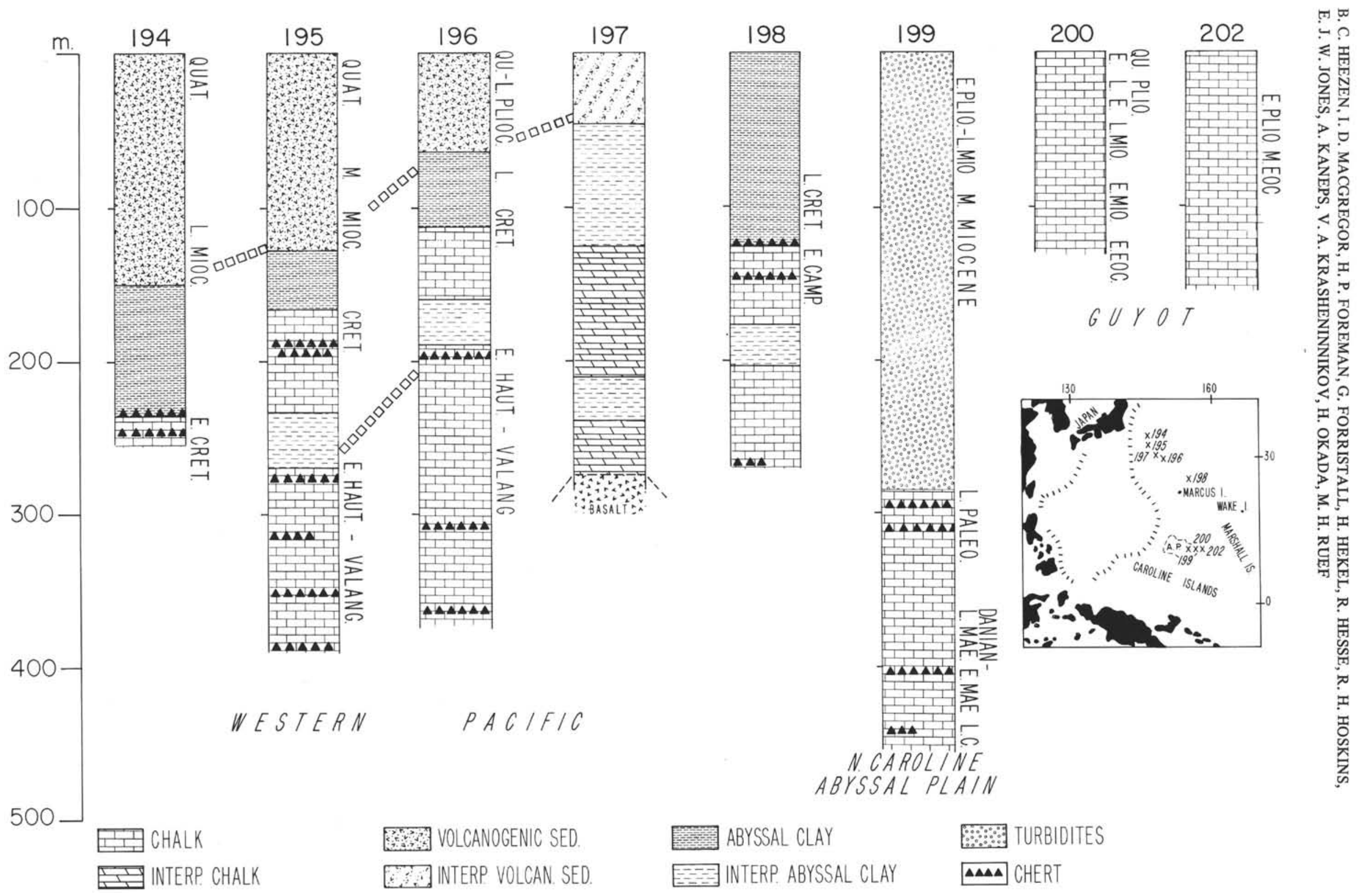

Figure 1. Summary of Leg 20 drilling results. Vertical columns indicate lithology versus age for each site. Extrapolations beyond total depth based on an interpretation of seismic reflection profiles obtained at each site. 
The Neogene gray to brown silty clays are composed primarily of quartz and feldspar with varying proportions of kaolinite and illite. There is an abundance of volcanic ash both as small layers and as pumaceous fragments. The ash layers consist for the most part of poorly sorted, angular, colorless glass shards with quartz and feldspar in minor amounts and accessory pyroxene and amphibole. Although concentrated in amounts in excess of 70 percent in the ashes, glass shards are also scattered throughout the clays. The clays are rich in radiolarians and diatoms.

The Cretaceous to Neogene darker brown to yellowish brown clay is composed of varying proportions of illite, kaolinite and montmorillonite, quartz, plagioclase, and clinoptilolite. Hydromicas are common in a few layers, and montmorillonite shows a general increase with depth. Cristobalite coexists with quartz in some of the deeper sections. Manganese micronodules vary in amounts from 1 to 10 percent and add to the darker brown color of the clay. Small cherty fragments and ash layers with glass shards occur toward the base of the unit. Radiolarians are occasionally found.

The underlying unit of Cretaceous chalks and cherts is composed of an interlayered sequence of nannofossil chalks, limestones, siliceous limestones, marls, and cherts with a few thin siltstone layers. The poor recovery from this unit does not allow estimates of thickness of the different layers, although variation in drilling rates suggests that the cherts are a few meters thick while the calcareous sediments may reach a few tens of meters in thickness. Within the chalk-chert sequence is an inferred unit of abyssal clay. Although this unit was not recovered, sudden increases of the drilling rates occurred at Sites 195 through 197. It is thought that this change correlates with the lower transparent layers of the acoustic profiles.

At Site 199, the lithology of the chalk-chert sequence is comparable to that of the northern holes. The interlayered Paleocene to Recent clay and nannofossil and radiolarian ooze is composed of a middle Miocene or younger unit of brown clays characterized by mixtures of kaolinite and montmorillonite with feldspar and minor quartz. The interlayers are of calcareous and siliceous fossiliferous oozes with mixed age assemblages. Tuffaceous layers are also present. The lithology of the mixed unit indicates an ambient deep-ocean environment with clay sedimentation and periodic influxes of fossiliferous oozes derived by gravity slumping from the Caroline Islands to the south. The basin lay below the carbonate compensation depth, and calcareous sediments may only be preserved during the rapid sedimentation attendant to gravity controlled turbid flows.

The nannofossil-bearing foraminiferal oozes covering the seamount drilled at Sites 200 through 202 constitute a well-winnowed pelagic ooze.

In a general way, the drilling rates may be related to lithology. Figure 2 shows the variation of drilling rates with depth in relation to the lithology being drilled. The features which may be observed are as follows: The upper clay unit, rich in volcanogenic remains, gives high and erratic values. During this stage of drilling, the drillers essentially try to emplace the drill collars in the soft sediments, and the drill rates reflect the cautious entry, combining "pushing ahead" and drilling rather than lithology. In the lower clay unit, the drilling rates become stable at values from 60 to 120 meters per hour with variability generally occurring between holes rather than within a single hole. The boundary between the lower clay and chalk-chert sequence is noted by a sudden drop in drilling rates to values between 40 and 60 meters per hour. Within the chalk-chert unit, the drilling rates are highly variable, with low values in the 10 to 25 meter-per-hour range and high values in the 30 to 80 meter-per-hour range. The variability probably reflects the interlayered sequence of chalks and cherts and gives some measure of the thicknesses of these units. Assuming that the lower drilling rates correlate with the cherts, and the higher rates with the chalks and limestones, it appears that while the chert layers are generally a few meters thick, the chalk layers are a few tens of meters in thickness.

The hole that best relates drilling rates to lithology is probably 197; drilling was continuous and no major disturbance of the hole was produced by coring. It is of interest to see the generally logarithmic decrease of drilling rate with depth, presumably indicating a general increase in induration of the clays. The chalk-chert sequence shows the same erratic drilling rates seen in the other holes and one layer with exceptionally high drilling rates can be seen. The sudden increases in drilling rate in the other holes at 220, 210, 220, and 165 meters at Sites 195, 196, 197 and 198, respectively, along with the sudden decreases in drilling rate are thought to delimit the lower transparent layer of the acoustic records. This layer is interpreted as a lower abyssal clay unit.

The oceanic crust of the western Pacific is overlain by a thick sequence of chalks, limestones, and cherts at least 200 meters and possibly as much as 400 meters thick. The age at the base of this unit has not been determined, although in the northwest Pacific it is definitely pre-Barremian, and estimates from the acoustic records and sedimentation rates suggest that it may be as old as early Jurassic. In the Caroline Abyssal Plain, the base of the unit is of pre-Campanian age.

The upper boundary of the chalk-chert unit is time transgressive, ranging in age from Barremian in the north to late Paleocene in the south. The overlying abyssal clay is also time transgressive, generally extending to the surface except in the three northernmost holes, where it is overlain by a Neogene wedge of volcaniclastic clays. In the northern region, the top of the abyssal clay unit decreases in age from early Miocene to Recent as one progresses from Site 194 to Site 198. The upper clay unit exists as a wedge-shaped unit, thinning to the east.

The acoustic records indicate that the chert-chalk and lower abyssal clay units cover the sea floor throughout the northwestern Pacific, and although the profiles for the Caroline Abyssal Plain suggest a thick sequence of turbidites comparable to that found at Site 199, the ambient conditions were generally comparable to those at the northern group of holes. The turbidites only represent transient events in the main continuing deep-sea environment.

\section{Summary}

The sea floor of the western Pacific is covered by five stratigraphic units: (1) a late Tertiary silty clay, primarily of volcanic origin, existing as a wedge thinning away from 
SITE 194 DRILL. RATE $\mathrm{m} / \mathrm{hr}$

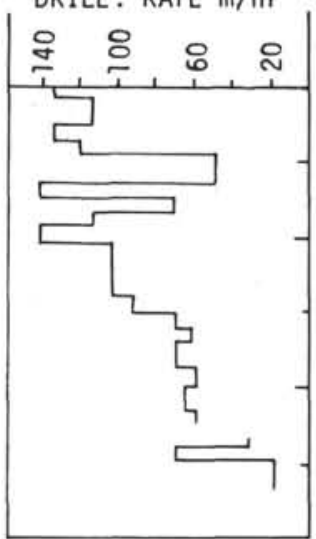

SITE 198

DRILL. RATE $\mathrm{m} / \mathrm{hr}$

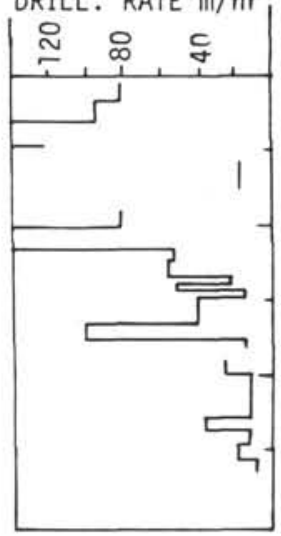

SITE 195

DRILL. RATE $\mathrm{m} / \mathrm{hr}$

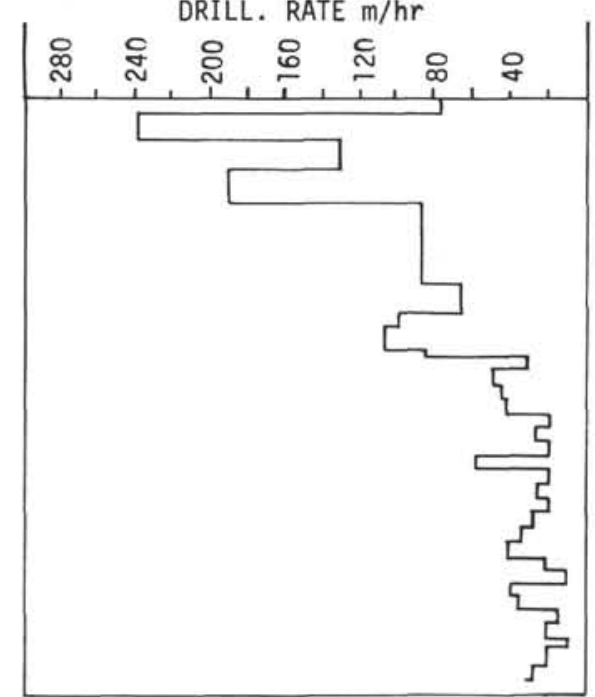

SITE 199

DRILL. RATE $\mathrm{m} / \mathrm{hr}$

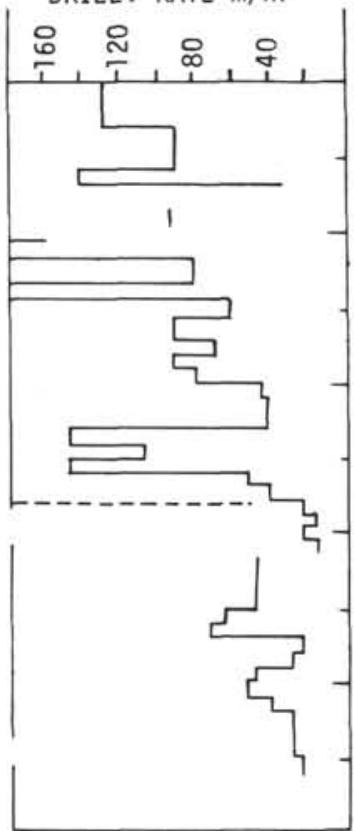

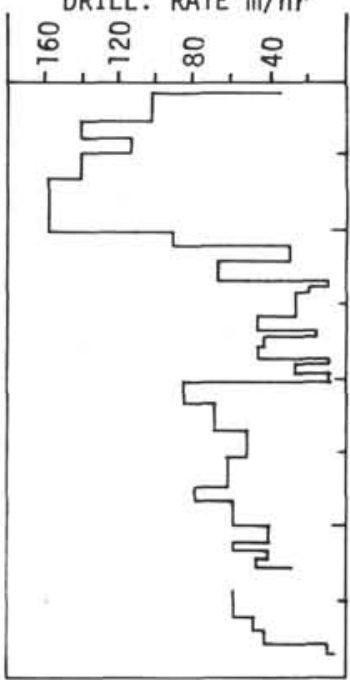

SITE 196

DRILL. RATE $\mathrm{m} / \mathrm{hr}$

SITE 200-201

DRILL. RATE $\mathrm{m} / \mathrm{hr}$

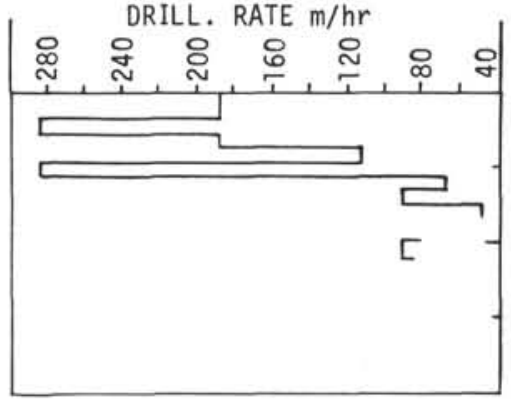

SITE 197

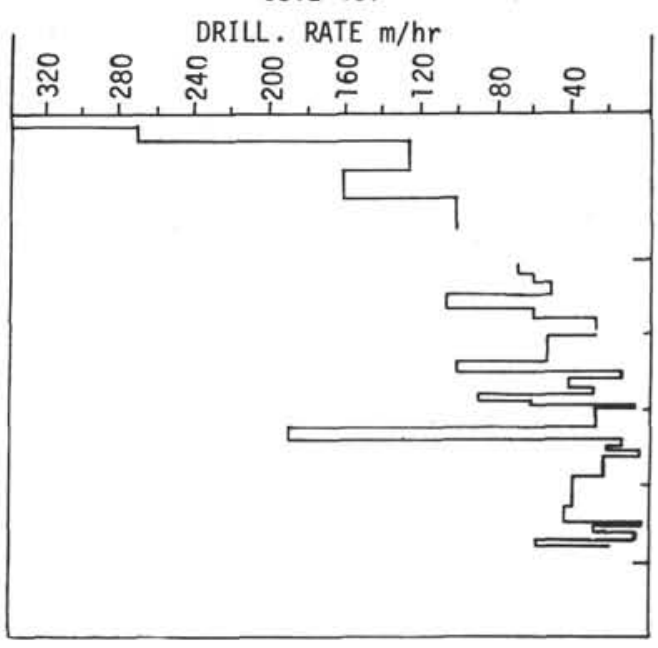

$\pi$

$-0$

₹园

요ㅈㅓㅛ

$>-$

睢

$<$ 尺

不

젖

品

褧
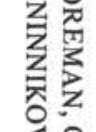

$<$

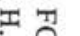

유ㅈㅠㅠ

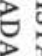

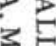

उद

I I

备

团

$\pi$

蒚

ติ

SITE 202

DRILL. RATE $\mathrm{m} / \mathrm{hr}$

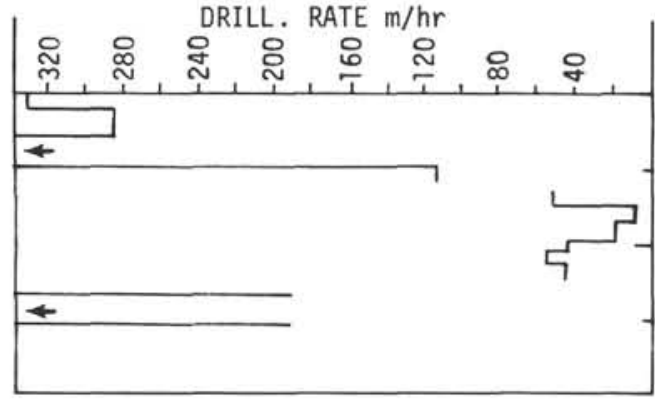

Figure 2. Drilling rate versus depth for each site. 
the Asiatic volcanic-arc source; (2) a Cretaceous to Tertiary zeolitic clay, which is the normal abyssal clay covering the whole area as a layer up to 100 meters thick; (3) a sequence (about $100 \mathrm{~m}$ ) of Cretaceous to Tertiary chalks and cherts; (4) an inferred earlier, thin abyssal clay a few tens of meters thick; and (5) basal, chalks, cherts, limestones, and marls of Cretaceous age and 200 meters or more in thickness (Figure 2). The underlying basement is pre-Neocomian in age. Variations of this stratigraphy are seen in areas where the oceanic crust has come under the influence of marginal rises or continental regions, for example, the Caroline Abyssal Plain, where late Tertiary abyssal clays are intercalated with redeposited calcareous oozes.

Drilling-rate changes in the lower carbonate/chert sequence suggest that the cherts are no more than a few meters thick but the calcareous units are probably tens of meters thick. The carbonate sequence is interrupted by a zone in which drilling rates are markedly higher and which apparently lacks cherts. This relatively thin layer, although unsampled, is assumed to consist of abyssal clay, and is equated with the earlier clay unit. The carbonate/chert units consist of the detrital remains of siliceous and calcareous organisms, which accumulated on this part of the ocean floor at times when it was above the effective local compensation depth.

\section{PELAGIC FACIES MODELS}

\section{Mid-Latitude Model}

The sedimentary history of an ocean basin is dependent on a number of variables, including the sediment source, solubility of the sediment components, the rate and direction of motion of the oceanic crust, the depth of the crust with respect to the solubility boundaries, and the rate of crustal subsidence. Oceanic pelagic sediments can be considered to consist essentially of two components-the organic remains of living organisms and an inorganic "clay" fraction. The organic remains consist primarily of the calcareous and siliceous tests of planktonic organisms. The tests dissolve during exposure to deep ocean water, their rate of solution being controlled by such physical factors as temperature and pressure and such kinetic factors as supply and removal rates of silica and calcium carbonate. For the calcareous and siliceous remains, this results in an effective depth below which no calcareous or siliceous remains are found known as the carbonate and silica compensation depths, respectively (Berger, 1967). Thus, the record of organic sedimentation on the ocean floor will depend on the depth relative to the appropriate compensation depth. In contrast, the inorganic clay component should be found at all depths. The other variables such as plate motion and crustal subsidence are only important in so far as they control the location of the plate relative to sources of supply and depth relative to the compensation depths.

Within the framework of plate tectonics, we can thus propose that as new oceanic crust is formed in the rift valley of a mid-oceanic ridge, a blanket of light-colored carbonate ooze begins to accumulate on the cooling basalt pillows (Heezen and Hollister, 1971). Chalk accumulation continues on the new crust until the subsiding sea floor drops below the carbonate compensation depth. Then, a layer of siliceous ooze should accumulate until the $/$ crust passes below the silica compensation depth, at which time a blanket of slowly accumulating abyssal clay begins to cover the biogenic layers (Figure 1).

Thus, new mid-latitude crust receives a layer of biogenic debris covered by inorganic abyssal clay. The thickness of the biogenic layer is determined by two factors: (1) the depth difference between the compesnation depth and the initial depth at the ridge crest, and (2) the rate of subsidence. In general, the compensation depth lies about 1,000 meters below the ridge crest, and new crust subsides about 50 meters per million years. This allows 20 million years of biogenic deposition before the onset of abyssal clay sedimentation. Sedimentation rates for pelagic biogenic deposits are less than 10 meters per million years. Thus, the basal calcareous and siliceous layers can normally be expected to not exceed 200 meters in thickness. Sedimentation rates for abyssal clay are generally significantly less than 1 meter per million years. Thus Early Cretaceous (120 million years old) crust formed under ideal mid-latitude conditions should have accumulated some 300 meters of sediments consisting of 200 meters of basal chalk and 100 meters of overlying abyssal clay.

However, comparison of the mid-latitude model with the stratigraphic sequence drilled during Leg 20 reveals serious discrepancies. Not only are chert/chalk sequences nearly twice as thick as predicted, but the span of time from the first chalk to the last chalk is closer to 50 million years than the 20 million years given by the model. The simple model outlined applies specifically to the mid-latitudes and the mid-ocean and may be modified by considering additional sources of sediments.

\section{Equatorial Model}

Anomalously high surface productivity may be expected to push the carbonate compensation depth ("chalk line") to much greater depths and may significantly increase rates of biogenic accumulation (Tracey, Sutton, et al., 1971). The most notable example of chalk-line depression occurs in a narrow zone between the northern and southern hemisphere current systems, beneath the narrow zone of equatorial upwelling (Arrhenius, 1952). Crust that forms under the equator and drifts east or west (parallel to the equator) may accumulate an enormous thickness of biogenic ooze.

The specific thickness of accumulation will depend on the rate and direction of crustal drift and the age of the crust at the time of equatorial passage (Arrhenius, 1952; Hays, Cook, et al., 1972). While crust drifting parallel to the equator may accumulate enormous thicknesses, particularly on young crust, crust drifting north or south receives a thinner chalk whose thickness depends largely on the rate of drift.

A belt of siliceous ooze lies between the equatorial zone of mainly carbonate deposition and the vast expanse of barren abyssal red clay which floors the deep Pacific. The presence of this belt of siliceous ooze deposition at the margins of the equatorial belt of productivity may be explained by the greater effective depth of silica 
compensation. The existence of the siliceous ooze zone allows us to predict the presence of siliceous units beneath and above ancient equatorial carbonates. As the crust moved under the equator, the equatorial carbonate would cover slightly older siliceous ooze, and as the superimposed equatorial carbonate deposit was moved from the equator, it in turn would be covered by another siliceous deposit (Figure 1). The resulting diachronous deposits of siliceous sediments would seem to be likely candidates for diagenetic conversion to bedded chert. Since the borders of the equatorial belts of carbonate and siliceous ooze are known to have suffered extensive fluctuations in the Quaternary, we may assume that alternations of thin siliceous and thicker carbonate oozes is an overall characteristic of equatorial deposition.

In practice, there appears to be a depth below which the chalk line may not be depressed. At present, this depth lies near 5000 meters. Ocean depth is a function of crustal age, a depth of 5000 meters generally corresponds to crust more than 50 m.y. old. Thus, crust older than 50 m.y. at the time of equatorial transit might be either deprived of an equatorial deposit or the transit may be represented by siliceous deposits or by a thin sequence of carbonates.

Can the anomalously great thickness of Cretaceous carbonates in the western Pacific be due to shifting of equatorial deposition? Let us consider the results of a site at the edge of the Caroline Abyssal Plain (199) which penetrated two main lithologies: a Quaternary to Eocene turbidite sequence overlying a thicker (at least $250 \mathrm{~m}$ ) sequence of interlayered chalks, cherts, and limestones of late Paleocene to Maastrichtian-Campanian age. Within the chalk/chert sequence there is an unconformity of Danian age.

Sites on an adjacent seamount $(200,202)$ showed that it is covered with Quaternary to early Eocene foraminiferal sand that overlies an oolitic limestone (pre-late Paleocene), indicating that this guyot was formed and eroded to sea level before this time and has since subsided 1600 meters to its present depth. Combining the seamount data with that of the adjacent deep-sea site, it may be concluded that the local effective carbonate-compensation depth at this location was at least as great as 5000 meters in late Paleocene time. The possibility that the carbonatecompensation depth was significantly deeper throughout the Pacific in the Paleocene can be excluded for lack of evidence of widespread Paleocene chalks in other deep-basin holes. Thus, in the late Paleocene, the equator was near $13.5^{\circ} \mathrm{N}$ at $150^{\circ} \mathrm{E}$.

The age of the chalk/chert-abyssal clay boundary may thus be used as an index of the equatorial transit. Specific ages from appropriate drill holes are shown in Figure 3. When combined with other evidence for equatorial transists (Tracey, Sutton, et al., 1971; Hays et al., 1972; Winterer, Ewing, et al., 1971; and Jackson et al., 1972), and the suggestion for a major change in the Pacific plate trajectory at about 30 million years, northward components of plate motion of $2 \mathrm{~cm} /$ year and $4.4 \mathrm{~cm} /$ year are obtained for the late Tertiary and the early Tertiary through Cretaceous, respectively. Similar evidence of northward plate motion has been inferred from studies of the remanent magnetism of cored basalts and seamounts (Francheteau et al., 1970; Winterer, 1972).

Thus, the mid-latitude and equatorial mid-ocean pelagic models, when combined, appear to compare favorably with the drilling results of the northern Pacific. The Cretaceous chalk/chert sequence that lies beneath the Tertiary and Late Cretaceous abyssal clay in the northwestern Pacific records the earlier Mesozoic passage of the ancient Pacific crust beneath the equator. The Lower Cretaceous chalk/chert sequence that lies at the bottom of the northern holes apparently represents the initial basal chalk formed on new crust, and the abyssal clay that separates the two units apparently records abyssal-basin sedimentation during the interval between the initial subsidence below chalk-line and the subsequent reoccurrence of chalk/chert deposition during the equatorial passage. The apparent success of the simple kinematic model in accounting for the stratigraphy of the western Pacific led us to examine more general implications of the model and to attempt a more analytical approach.

\section{Analytical Model of Pacific Sedimentation}

The following numerical values have been used in the calculation of the Pacific sedimentation models (Figure 4; see also Forristall, Chapter 29, this volume).

1) Crust formation at ridge crest at 3000 meters depth

2) Compensation depth at depth of 3700 meters

3) Ridge crest subsides at rate of 35 meters per million years

4) Sediment accumulation rates:

a. Axial organic sediments at 10 meters per million years

b. Abyssal clay at 1 meter per million years

c. Equatorial organic sediments at an additional 10 meters per million years

5) Zone of equatorial sedimentation is $5^{\circ}$ wide

6) Trajectories of Pacific plate:

a. "Westward" component (approximately parallel to fracture zones, $259^{\circ}$ azimuth)

b. Northward component

(1) $2 \mathrm{~cm}$ per year from 0 to 30 million years

(2) $4 \mathrm{~cm}$ per year from 30 to 200 million years

7) Orientation of crossections:

a. $79^{\circ}$ azimuth, intersecting $160^{\circ}$ at $0^{\circ}$

b. $79^{\circ}$ azimuth, intersection $160^{\circ}$ at $15^{\circ} \mathrm{N}$

c. $79^{\circ}$ azimuth, intersecting $160^{\circ}$ at $30^{\circ} \mathrm{N}$

8) Compensation depth rises above ridge crest from 60 to 110 million years (perturbation introduced to account for absence of axial ridge organic sediments in data cross sections; Figures 5 and 6).

Basically, the mathematics of the model is a simple bookkeeping operation. Consider a section perpendicular to the ridge crest. Whatever the relative motion of the equatorial zone, it may be described by its speed and width projected on the section. At each step in time, we must then calculate which rates of sedimentation apply to each point on the crust and add that then deposited to the thickness already there. Then at suitable time intervals, isochrons can be drawn through the thickness generated to produce a model geologic section. Several parallel sections 


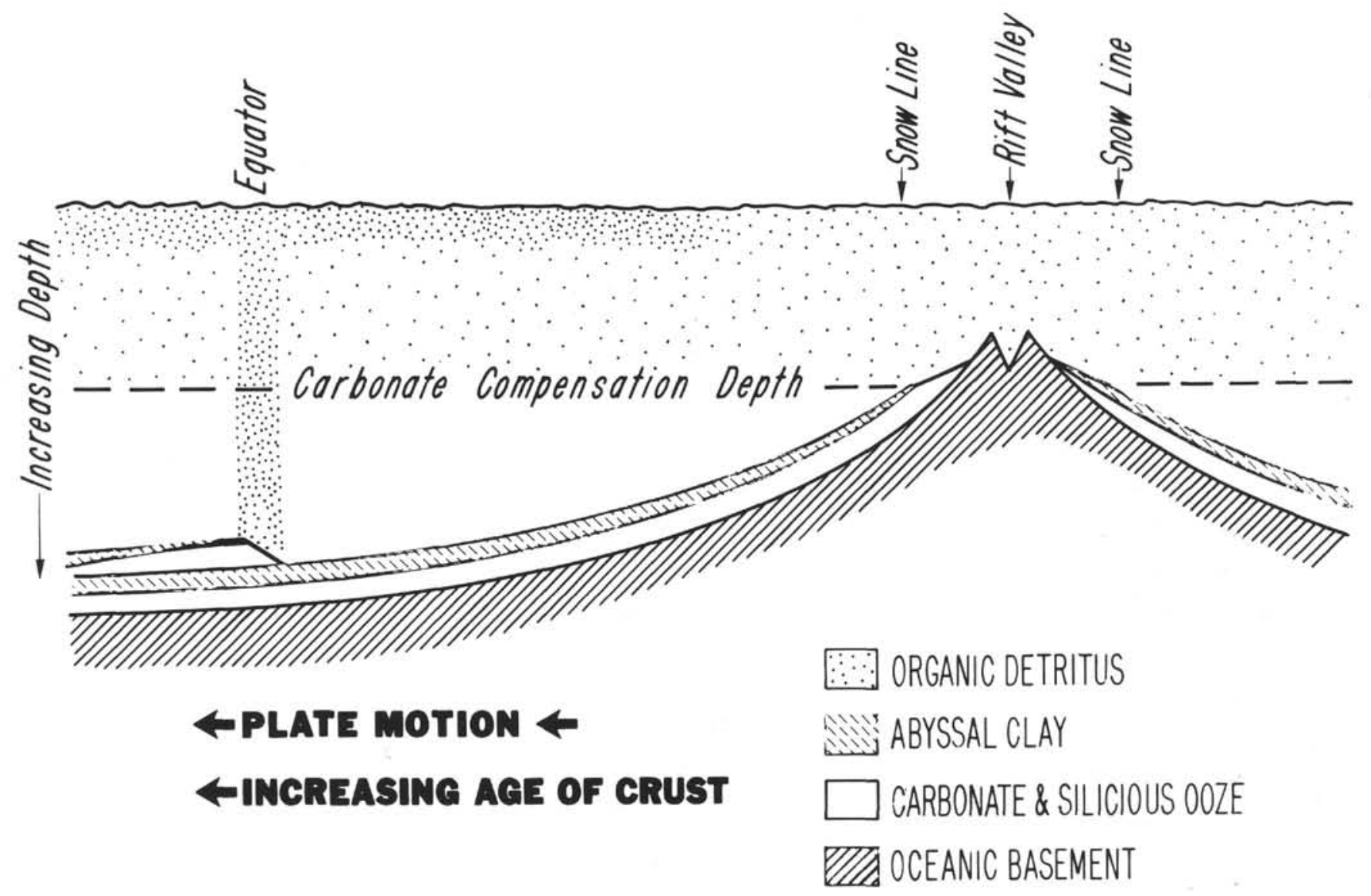

Figure 3. Model of sedimentation on axially accreting oceanic crust. There may not be a silica compensation depth in the same sense that there is a carbonate compensation depth but there is reason to believe that silica may be deposited at any depth given high productivity of silica-secreting organisms.

based on the same parameters give a rather complete history of sedimentation (Figure 4). A vertical trace at the appropriate place on the model section may then be compared with a bore hole from the locality.

Employing the method described above, a model has been calculated for a profile across the Pacific from the modern ridge crest off California to the Mesozoic crust off the Mariana Arc. (Figure 4). We can now compare this model with the generalized stratigraphy reported from Pacific deep-sea drilling.

\section{SUMMARY OF PACIFIC STRATIGRAPHY FROM DSDP DATA}

Shown in the vertical columns in Figure 5 are the basic data from bore holes projected to the lines of section. Figure 6 illustrates an interpolated summary of the distribution of the different major lithologies in the Pacific.

A comparison of the model (Figure 4) with the observed stratigraphy (Figure 6) and stratigraphic summary (Figure 7) reveals the following agreement:

1) The Pacific crust ages from east to west, an observation justifying a basic assumption of the model.

2) The basal chalk/chert unit is time transgressive, increasing in age from east to west. In the eastern Pacific, the basal carbonate is about 50 to 200 meters thick (or about 20 to 40 million years in extent), indicating a general agreement with the model. The basal chert/chalk is interpreted as that accumulated at the ridge prior to its submergence beneath the compensation depth.

3) Both have an upper chert/chalk unit which is only present in the western Pacific. This unit is also time transgressive, increasing in age from the Equator northwards, and from east to west. This unit is interpreted as the biogenic ooze accumulated during the passage of the Pacific crust beneath the Equator.

4) The upper and the lower chert/chalk units merge in the mid-Pacific with the existence of a chevron pattern as predicted by the model.

5) Two abyssal clay units are observed. The lower unit consists of a wedged-shaped horizon, whose upper and lower boundaries are time transgressive, and which wedges out increasingly westwards for the more northerly sections. The base of the lower clay is the chert/chalk sequence accumulated at the ridge, and the top, the chert/chalk sequence deposited during the equatorial crossing. The upper clay unit is found only in the northern Pacific, wedging out to the Equator in the south, and younger crust to the east.

Other features observed in the data summary (Figure 6) but not included in the model (Figure 4) are:

1) Where the oceanic crust has passed close to a continental margin, positive area, or extinct volcano, we see 

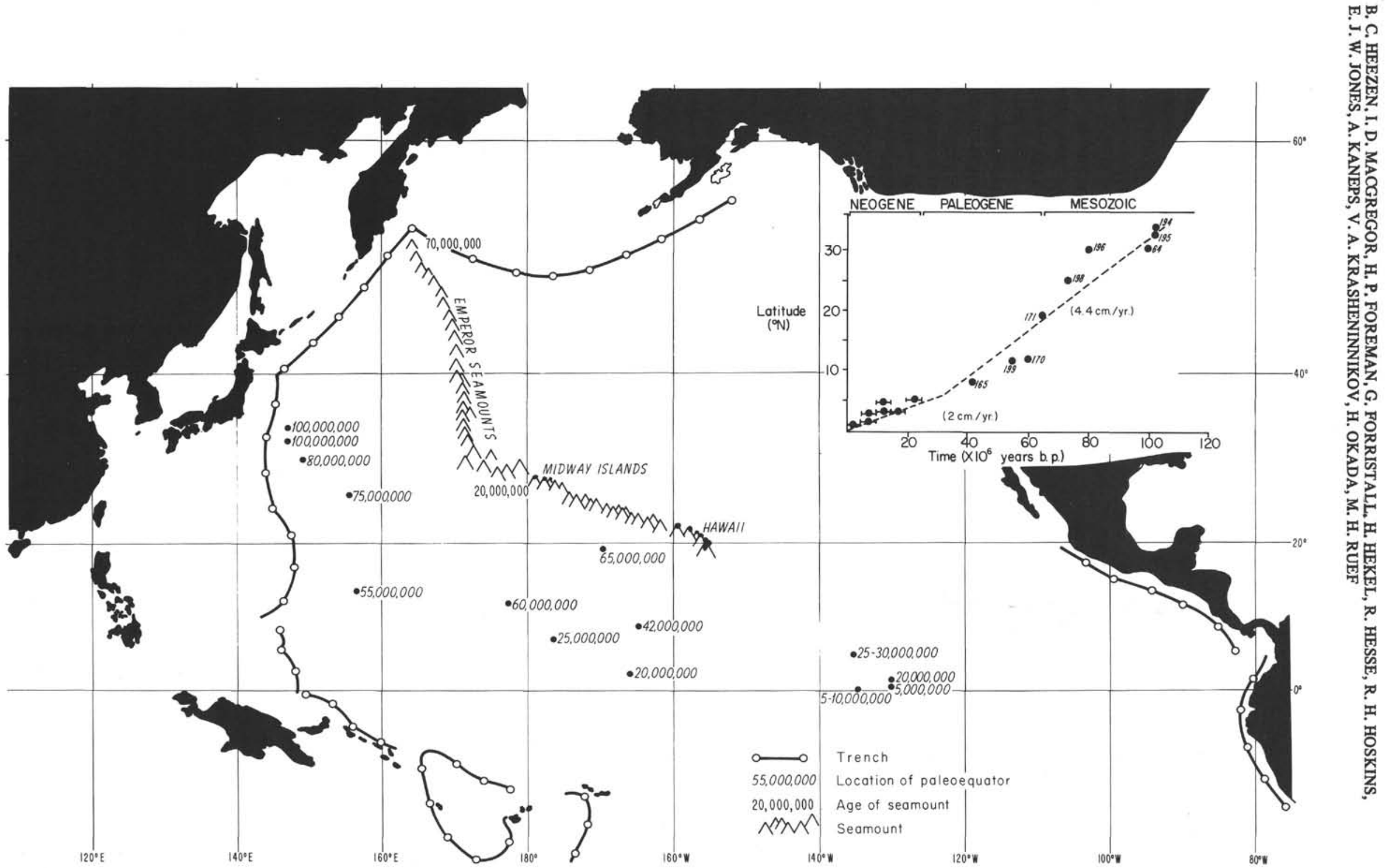

Figure 4. Locations of paleoequators on the Pacific plate based on DSDP results. Age of transit shown in millions of years. Upper right hand insert shows northern component of crustal motion against age in millions of years. 

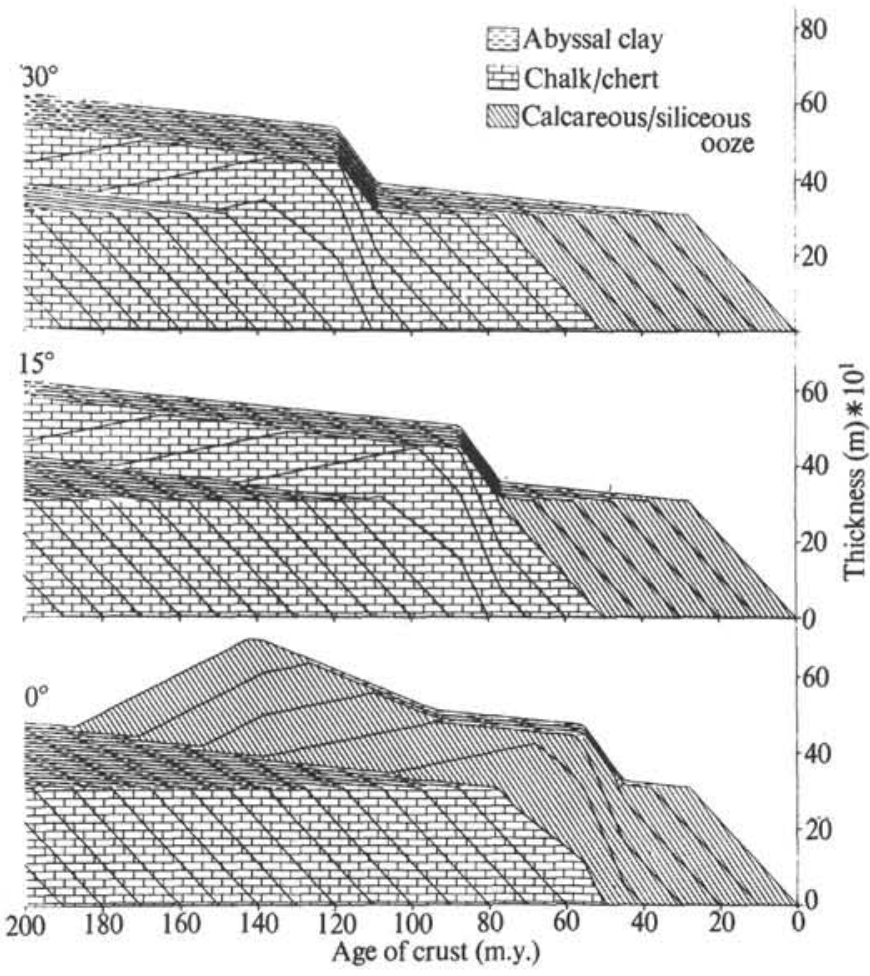

Figure 5. Computed models of Pacific Ocean sedimentation history. The method of calculation employed is described by Forristal in Chapter 29.

the addition of turbidite or volcanogenic sediments. Good examples are the wedge of turbidites along the west coast of North America (Creager, Scholl, et al., 1971; Von Huene and Kulm 1971), the turbidites filling the Caroline Abyssal Plain, and the wedge of wind-blown volcanogenic debris east of the Asiatic arcs (Heezen, MacGregor, et al., 1972).

2) The presence of equatorial organic oozes along the whole length of the present Equator, and the absence of this unit in any section south of the Equator.

3) The onset of lithified chalk/chert sequences from calcareous and siliceous oozes at a crustal age of about 50 million years.

In general, there is a close fit between the model and data summary with respect to the distribution pattern, timing, and thicknesses of the major lithologies. The fit is encouraging and lends credence to the model as a useful first order approximation of the sedimentary history of the Pacific plate. Departures from the model should now illustrate smaller or more local events in the sedimentary history and add detail to the geologic history of the Pacific.

\section{ACOUSTIC STRATIGRAPHY}

The major boundaries separating the lithologic units which lie between the sea floor and the oceanic basement provide the strong contrasts in acoustic impedance necessary to create major reflectors of regional extent. Let us compare the pattern of lithic units predicted by the kinematic model with the acoustic stratigraphy revealed by seismic reflection profiling in the Pacific basin (Ewing et al., 1968).

Seismic reflection profiling has defined five acoustic units in the Pacific: (1) an upper transaural or transparent layer lacking strong reflectors, (2) a unit consisting of closely spaced strong reflectors known as the opaque layer, (3) a lower transparent layer which is of smaller regional extent than the overlying layers, (4) a lower opaque layer of limited extent, and (5) basement, which, if smooth, is referred to as Horizon B. The upper transparent layer corresponds to the abyssal clay in the west and central Pacific, turbidite sequences in the north and east, and unconsolidated organic oozes in drillings to the east and along the Equator. The opaque layer corresponds to the thick carbonate/chert sequence of the western Pacific. The locally occurring lower transparent layer may correspond to the Cretaceous clay of deep-sea drilling, and the lower opaque layer corresponds to the basal carbonate/chert in areas which having crossed the equator have acquired additional carbonates higher in the section.

Previous interpretations of the acoustic records evidenced a strong preference for the synchroneity of acoustic boundaries (i.e., lithic boundaries), suggesting Eocene or late Maastrichtian ocean-wide or even world wide horizons, apparently resulting from synchronous global events.

However, the top of the opaque layer is widely time transgressive. Thus, the former assumption of synchroneity simply does not conform to the evidence from deep-sea drilling and is in conflict with the kinematic model of lithologic stratigraphy. Similarly, the assumption that the opaque layer is a clastic wedge may be disproved by the drilling results.

The acoustic data themselves, when stripped of the synchronous time-stratigraphic interpretation, can, however, be compared favorably to the kinematic model offered in explanation of the drilling results. The opaque layer evidently is a carbonate-chert sequence deposited, at least in part, under equatorial conditions. The area of the Pacific in which the opaque horizon is observed is that portion of the crust which has passed under the equator (Figure 8). The limits of the opaque layer are the equator on the south, the subducting arcs on the west, and a line, marking the limit of crust created subsequent to the equatorial passage, on the northeast. The opaque layer is apparently thickest between $20^{\circ}$ and $30^{\circ} \mathrm{N}$, a fact which may be explained by a smaller northward component of drift of the Pacific crust in Early Cretaceous time, an effect similar to that recorded for Neogene time by the equatorial sediment bulge. The acoustic stratigraphy thus seems adequately accounted for by the kinematic model.

Certain further predictions can be made:

1) On crust of a given age, the total thickness of pelagic deposits should be markedly less in the South Pacific, which has yet to receive an equatorial contribution, than in the North Pacific, where equatorial deposition has already produced an additional layer of carbonates,

2) South of the equator in the Pacific, cherts should be much less common than to north of the equator.

Thus, the new kinematic stratigraphy of pelagic deposits, which predicts a characteristically diachronous behavior of units, can be applied to acoustic stratigraphy as well as to lithostratigraphy.

\section{MAGNETIC DATA}

Stripe-like magnetic anomalies generated by east-west axial acretion are either absent or poorly developed in crust 


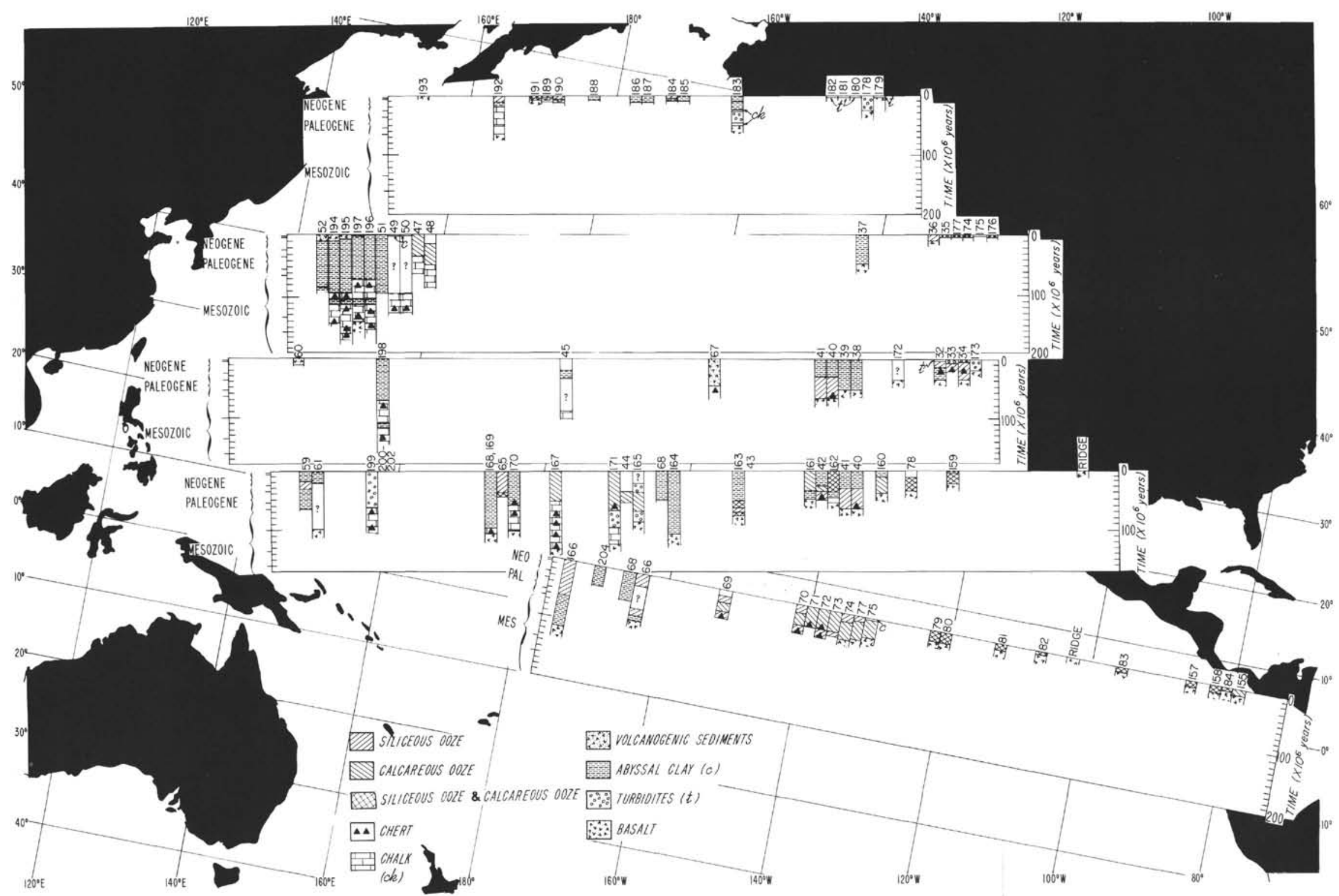

Figure 6. Summary of lithology versus age for Pacific DSDP sites through Leg 20. Sites are projected to construct five trans-Pacific profiles. 


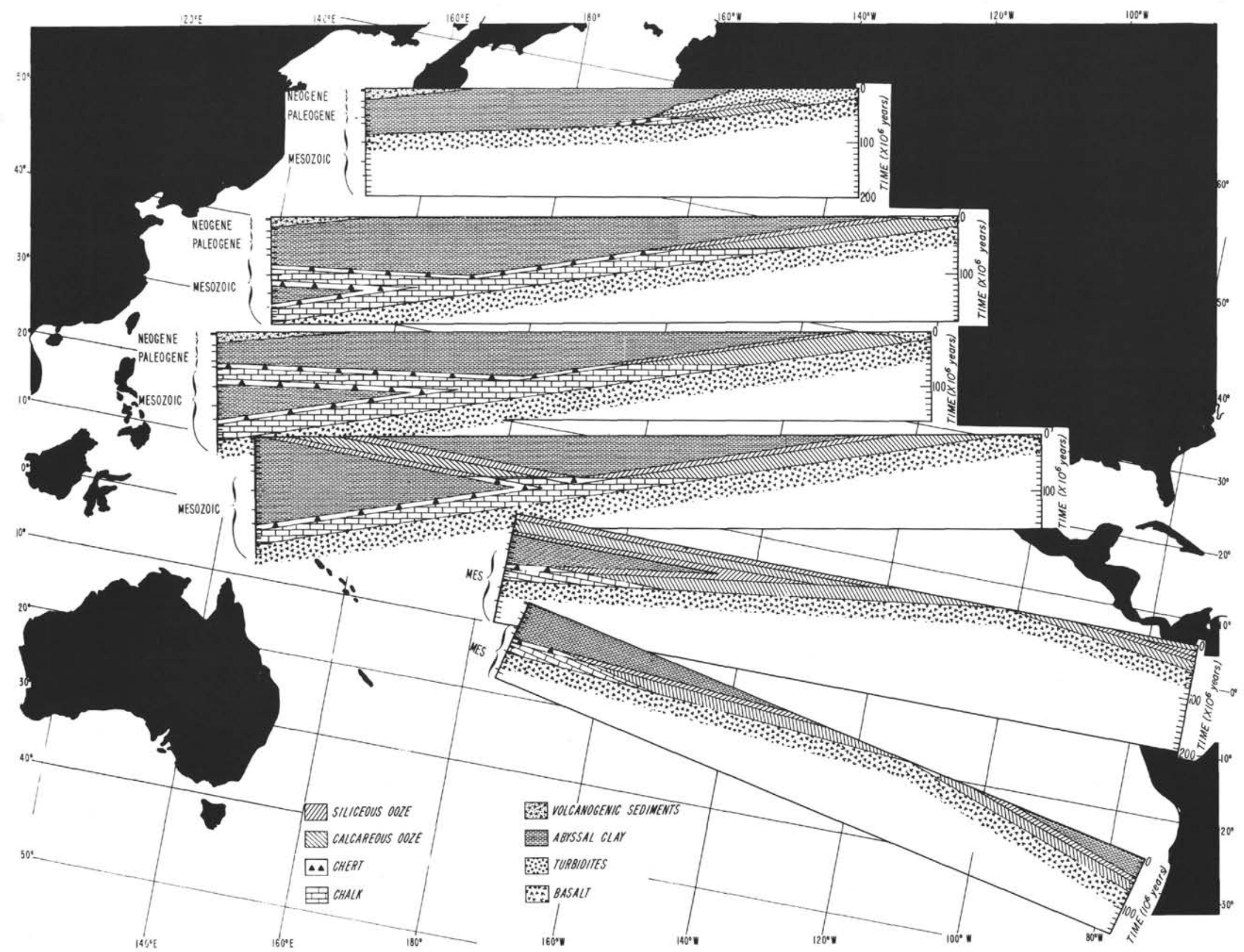

Figure 7. Lithology versus age cross sections of the Pacific based on DSDP data. Diachronous interpretation based on model of sedimentation on axially accreting oceanic crust. 
B. C. HEEZEN, I. D. MACGREGOR, H. P. FOREMAN, G. FORRISTALL, H. HEKEL, R. HESSE, R. H. HOSKINS, E. J. W. JONES, A. KANEPS, V. A. KRASHENINNIKOV, H. OKADA, M. H. RUEF

generated at the magnetic equator. A magnetically quiet zone has been mapped in the mid and high latitudes of the north central Pacific. The zone apparently extends through the eastern Pacific from the present intersection of the magnetic equator with the axial rift valley towards the northwest Pacific passing through a point a few hundred $\mathrm{km}$ east of Hawaii (Figure 8).

This magnetic quiet zone lies somewhat east of the easternmost sites which sampled equatorial carbonates and just east of the limit of the acoustic opaque layer. It has been generally assumed that the magnetic quiet zone is to be explained by a long period in the Cretaceous period during which magnetic reversald did not occur (Hayes and Pitman 1970). Although this explanation may be true in part, no data have yet been presented in the literature to clearly cupport this assumption. The magnetic quiet zone is in fact predicted by the kinematic model of pelagic stratigraphy.

Given

1) the emperical and theoretical observation that large magnetic anomalies are not associated with north-south linear rock bodies formed near the equator;

2) the pattern of ages of crust increasing to the west; and

3) the distribution of equatorial deposits in the western Pacific;

the conclusion can not be escaped that a magnetic quiet zone, which marks locus of points representing the intersection of the ridge axis and the equator, should exist.

If there was indeed a period without reversals during the Cretaceous, its effect would be to widen the apparent intersection and introduce other details.

The acoustic opaque layer cannot be mapped in the northernmost western Pacific for the practical reason that the lower transparent layer pinches out a few hundred kilometers northwest of the Shatsky Plateau. This pinchout suggests that the basal carbonates merge with the equatorial carbonates perhaps because the period of time separating the original generation of this crust and the equatorial transit of that crust was too brief to be represented by a layer of abyssal clay thick enough to be detectable by seismic reflection profiling. Since the rate of abyssal clay deposition is so slow that a layer only 10 or 20 meters thick may represent as many, or more, millions of years, the true pinchout could be a considerable distance northwest of the pinchout shown by reflection records.

Thus, the crust of the Pacific somewhat northwest of the lower transparent layer pinchout would seem to have been formed very near the equator in pre-Hauterivian time.

The northwestern corner of the Pacific south of the western Aleutians is reported to be magnetically quiet, and this observation is thus consistent with the inferences drawn from the stratigraphy. It is concluded that the magnetic quiet zone of the northeast Pacific is indeed the quiet zone predicted by the kinematic model. We can thus divide the Pacific crust into two regions, one formed before, and a second after, the equatorial crossing. The boundary between the two is the "magnetic quiet" zone (Figure 8). Similarly, the restriction of thick opaque layers to the western Pacific results in the correlation of this region with that portion of the Pacific crust that has passed beneath the equator and thus received a double layer of biogenic sediment.

\section{DIACHRONOUS DETRITAL DEPOSITS ON THE MARGINS OF THE PACIFIC PLATE}

Evidence of crustal motions may also be derived from diachronous volcanic deposits near plate margins. A detrital wedge of volcanic debris is found within $1000 \mathrm{~km}$ of the Asiatic arcs in the northwest Pacific (Figure 6). The shape and extent of the wedge is a function of two counterbalancing effects; the amount and extent of distribution of volcanic debris and the westward subduction of the Pacific plate. Assuming that the rates of both processes have been essentially constant during late Tertiary time, equilibrium should result and the shape of the wedge would stay essentially constant. Near the distal edge of the wedge (Sites 194, 195, 196), late Tertiary sedimentation rates are approximately the same. Thus, the difference in thickness of the wedge between sites may be ascribed purely to the older age of the initial deposition surface at the thicker sites. With the above assumptions, a value of about $8 \mathrm{~cm}$ a year is obtained for the westward component of drift of the crust, i.e., the subduction rate into the marginal trenches. This rate is of the same magnitude as the axial accretion rates determined for the past few million years by the magnetic stripes at the crest of the mid-oceanic ridge. Although the measurement is admittedly crude (3) the method seems to hold promise if more holes could be obtained through the volcanic wedge off the Kuril Islands, Japan and the Aleutians. Other marginal detrital deposits may be synchronous, for example, the cut off of turbidites to the relic Aleutian Abyssal Plain by the blockage of the Aleutian Trench, or the commencement of turbiditic deposition on the Caroline Abyssal Plain by the creation of a source area in the Caroline Islands.

Whereas detrital sediments deposited in the deep sea may be broadly synchronous, the characteristic stratigraphy of pelagic deposits is broadly and systematically diachronous. The history of the Pacific plate has apparently been governed by a few simple and systematic factors: the carbonate and silica compensation depth, the gradual sinking of oceanic crust, and the northward migration of the Pacific crust beneath the paleoequator.

While we are gratified by the apparent close agreement of data and model we wish to emphasize the severe limitations of both. The model presented here has ignored both the theoretical effect of reversals in plate motion on bed thickness and possible evidence of such reversals. We have considered only a few changes in direction and rate of crustal drift and ignored possible changes in sea level or compensation depth.

In our opinion, a relatively small number of additional holes drilled in the more ancient parts of the ocean would provide data for a greatly refined model. It would seem that even with only a few dozen better located, well sampled bore holes in the ancient Pacific plate we could, with the aid of a kinematic model, arrive at a rather detailed history of the Pacific since the Jurassic. 

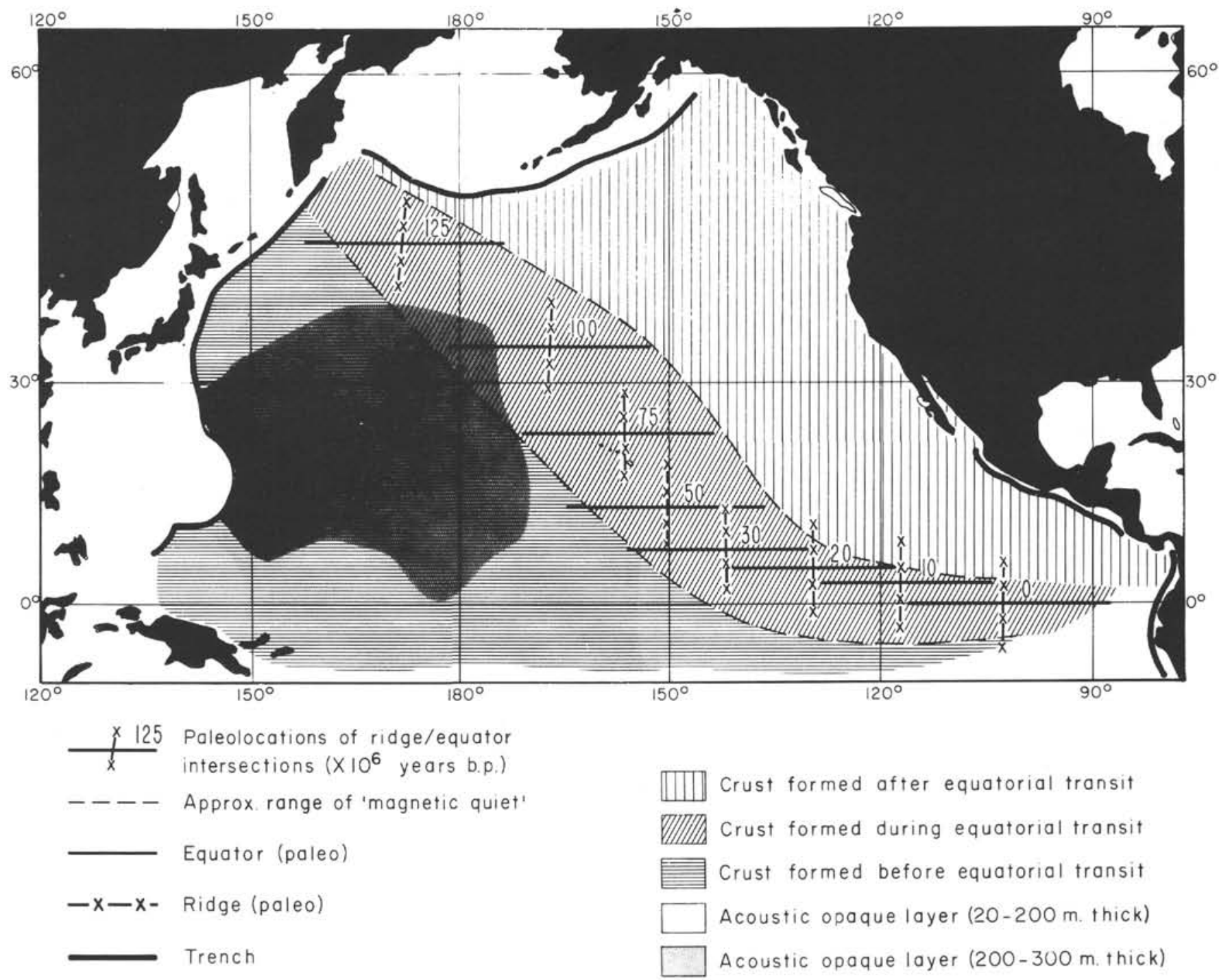

Figure 8. Age structure of Pacific crust. The opaque acoustic layer is limited to the nor thern hemisphere and occurs on crust formed south of the equator. The magnetic quiet area represents crust formed by east-west accretion near the magnetic equator. The magnetic quiet zone separates crust which received an equatorial contribution of chert and chalk from crust which possess a single carbonate sequence on basement.

\section{REFERENCES}

Arrhenius, G., 1952. Sediment Cores from the East Pacific: Rept. Swedish Deep-Sea Exped. (Goteborg), v. 5, 227 p.

Berger, W. H., 1967. Foraminiferal ooze: solution at depth: Science, v.156, p. 383-385.

Craeger, J. S., Scholl, D. W., Stewart, R. J., Fullam, T. J., Supko, P. R., Echols, R. H., Ling, H. Y., Worsley, T. R., Koizumi, I., Boyce, R. E., Grow, J. A., Lee, J. H., Ericson, A., Hess, J., Bryan, G., and Stoll, R., 1971. Deep Sea Drilling Project, Leg 19: Geotimes (Nov.) p. 12-15.

Ewing, J., Ewing, M., Aitken, T., and Ludwig, W. J., 1968. North Pacific sediment layers measured by seismic profiling. In The crust and Upper Mantle of the Pacific Area: Am. Geophys. Union Mon. 12, p. 147-173.

Fischer, A. G., Heezen, B. C., Boyce, R. E., Bukry, D., Douglas, R. G., Garrison, R. E., Kling, S. A., Krasheninnikov, V., Lisitzen, A. P., and Pimm, A. C., 1971. Initial
Reports of the Deep Sea Drilling Project, Volume VI: Washington (U. S. Government Printing Office), 1329 p.

Francheteau, J., Harrison, C. G. A., Sclater, J.G., and Richards, M. L., 1970. Magnetization of Pacific seamounts; a preliminary polar curve for the northeastern Pacific: J. Geophys. Res., v. 75, p. 2035=2061.

Hays, J. D., Cook, H. E., Jenkins, D. G., Cook, F. M., Fuller, J. T., Gall, R. M., Milow, E. D., and Orr, W. N., 1972. Initial Reports of the Deep Sea Drilling Project, Volume IX: Washington (U.S. Government Printing Office), $1204 \mathrm{p}$.

Hayes, D. E., and Pitman, W., III., 1970. Magnetic Lineations in the North Pacific: Geol. Soc. Am., Mem. 126, p. 291-314.

Heezen, B. C., and Hollister, C. D., 1971. The Face of the Deep: London (Oxford University Press), 659 p.

Heezen, B. C., MacGregor, I. E., Forman, H. P., Forristall, G., Hekel, H., Hesse, R., Hoskins, R. H., Jones, E. J. W., Kaneps, A., Krasheninnikov, V. A., Okada, H., Ruef, 
M. H., 1972. Deep Sea Drilling Leg II: Geotimes, v. 17 (No. 4), p. 10-14.

Jackson, E. D., Silver, E. A., and Dalrymple, G. B., 1972. Hawaiian-Emperor chain and its relation to Cenozoic circum-Pacific tectonics: Geol. Soc. Am. Bull., v. 83, p. 601-618.

Maxwell, A. E., Von Herzen, R., Andrews, J. E., Boyce, R. E., Milow, E. D., Hsu, K. J., Percival, S. F., and Saito, T., 1970. Initial Reports of the Deep Sea Drilling Project, Volume III: Washington (U.S. Government Printing Office), $806 \mathrm{p}$.

McManus, D. A., Burns, R., Weser, O., Vallier, T., Von der Borch, C., Olsson, R. V., Goll, R. M., and Milow, E. D., 1970. Initial Reports of the Deep Sea Drilling Project, Volume V: Washington (U.S. Government Printing Office) $827 \mathrm{p}$.

Tracey, J. I., Jr., Sutton, G. H., Nesteroff, W. D., Galehouse, J., Von der Borch, C. C., Moore, T., Lipps,
J., Bilal Ul Haq, U. Z., and Beckmann, J. P., 1971. Initial Reports of the Deep Sea Drilling Project, Volume VIII: Washington (U. S. Government Printing Office), 1037 p.

Vine, F. J., 1968. Paleomagnetic evidence for the northward movement of the North Pacific Basin during the past 100 m.y. (Abs.): Am. Geophys. Union Trans., v. 49 , p. 156.

Von Huene, R., Kulm, L. D., Duncan, J. R., Ingle, J. C., Kling, S. A., Musich, L. M., Piper, D. J. W., Pratt, R. M., Schrader, H. J., Weser, O., and Wise, S. W., 1971. Deep Sea Drilling Project Leg 18: Geotimes (Oct), p. 12-15.

Winterer, E. L., 1972. Geologic History of Pacific Ocean: Am. Assoc. Petrol. Geol. Bull., v. 56, p. 63.

Winterer, E. L., Ewing, J., Schlanger, S. O., Moberly, R. M., Lancelot, Y., Jarrad, R. D., Douglas, R. G., Moore, T. E., and Roth, P., 1971. Deep Sea Drilling Project Leg 17: Geotimes (Sept.), p. 12-14. 